\title{
Isolations \& Characterization of Compounds from Cordia macleodii Hook Bark \& Leaves
}

\author{
Dr.O. N. Chaubey*, Dr. Ravi Upadhyay, Niraj Kumar Tripathi, Amulya Ranjan \\ Chemistry Department, Govt. Narmada P.G. College, Hoshangabad (M.P.) India 461002
}

\begin{abstract}
Cordia macleodii Hook (boraginaceae), a folklore medicinal plant, commonly known as "Shikari" in local language and found in Odisha and Madhya Pradesh. In this study, phenolic \& flavonoid compounds isolated \& characterized form the ethanolic extract of Cordia macleodii Hook (Boraginaceae). Present research, material isolation is disclosed from bark \& leaves of Cordia macleodii hook \& characterisation of intended compounds have been done.
\end{abstract}

Keywords: phenolic flavonoids, phytochemical screening, Cordia macleodii

\section{Introduction}

Cordia macleodii Hook (Boraginaceae) known Dahipalash (Hindi) or Dhaman (Marathi) or Panki/Shikari (Tribals), is a small tree $(8-10 \mathrm{~m})$ having white colour flower and ovate leaves $(5-10 \mathrm{~cm})$, native to India. Various parts of the plant are used by tribal people and traditional medical practitioners of Odisha, Madhya Pradesh and Chhattisgarh in the treatment of many diseased conditions. Leaves are used in wound healing, mouth sore; seeds as an aphrodisiac; stem in wound healing, while bark is used in the treatment of jaundice. Plant contains alkaloids, glycosides and tannins. Ethanomedicinal claims have not been evaluated pharmacologically except for hepatoprotective (leaf), wound healing (leaf and bark) and antimicrobial and antifungal (leaf and bark). Present study was an attempted to isolation \& characterisations of phytoconstituents from bark \& leave part of Boraginaceae plant Cordia macleodii hook.

\section{Experimentation}

Dried bark \& leave of Cordia macleodii Hooks are taken for extraction in ethanol with the help of soxhlet apparatus. Each extract was further concentrated on water bath evaporation the solvent ethanol completely to obtain the solid crude extract.

Obtained extract evaluated phytochemically by using Khandelwal, 2005 methods to test for alkaloids, glycosides, tannins, phenols, saponins, flavonoids and terpenoids. This test shows the ethanolic extracts of Cordia macleodii Hook was found highly rich in flavonoids and phenolics contents.

Phenolic compounds are a class of antioxidant agents which act as free radical terminators and their bioactivities may be related to their abilities to chelate metals, inhibit lipoxygenase and scavenge free radicals. The amount of total phenol \& flavonoids content were determined with the Folin-Ciocalteu reagent $\&$ in term of Gallic acid equivalent (GAE).

These extract are tested against antimicrobial activity in which bark extract shows antimicrobial activity against Comamonas testosteroni \& Pseudomonas plecoglossicida at higher concentration. We have reported antimicrobial activity in IOSR Journal of Pharmacy as "Comparative Antimicrobial Study of Cordia macleodii Hook" Dr.Om Narayan Chaubey, Dr. Ravi Upadhyay, Niraj Kumar Tripathi, Amulya Ranjan, IOSR Journal of Pharmacy \& Biological Science (IOSR-JPBS), 2319-7676. Volume 10, Issue 3 Ver .I. (May-June 2015), PP 01-03.

In continuation, since extracts are rich in phenolic \& flavonoids contents, taken for isolation of compounds by used of chromatographic technique.

After applying column chromatographic technique, pure fractions obtained from bark \& leave ethanolic extract of concerned plant.

\section{Result \& Discussion}

Spectral analysis was performed to characterise the isolated compounds obtained from ethanolic extracts of bark $\&$ leave of Cordia macleodii Hooks.

Bark fraction's isolated compound spectral analysis explains the structures which were obtained the course of column chromatography.IR spectra (in $\mathrm{KBr}$ ) showed absorption band at 3495.12 ( $\mathrm{OH}$, stretch), 1696.43 (C=O, stretch), 1610.55, 1537.28, 1427.20 (C=C stretch), 1309.07 (OH, In-plane bend), 1246-1199 (CO stretch), 1023.81 (OH, Out-plane bend), 864.49 (Ar-H, Out of plane bend). The UV spectrum of isolated compound has characteristic bands at $\lambda 256 \mathrm{~nm}$ and $371 \mathrm{~nm}$ which lead to conclusion that the compound belongs to the group of flavonoids. HNMR \& C NMR was recorded on Bruker DRX -300 (300 MHz FT-NMR) 
in DMSO + D2O, using TMS as internal standard. The H-NMR \& C-NMR spectral data of isolated compound is shown in table 1. Mass spectral data exhibited molecular weight of compound is 300.31 .<smiles>Cc1cc(O)cc(CC2CC(=O)c3c(O)cc(O)cc3O2)c1</smiles>

Compound isolated from ethanolic extract as pale yellow powder of melting point $311-315^{\circ} \mathrm{C}$, yellowish colour under UV Light. Soluble in ethanol, methanol, chloroform, DMSO and partially insoluble in water, identified as that the compound is the derivative of Quercetin as interpreted from the different spectra.

The chromatographically pure fraction obtained from leave of Cordia macleodii Hook which was characterized after recrystallization with ethanol. IR spectra (in $\mathrm{KBr}$ ) showed absorption band at stretching band at $3259.95 \mathrm{~cm}-1$ (s) due to $\mathrm{OH}$ stretching; at 3015.23 (s) due to Aromatic $\mathrm{CH}$ str.; 2932.28, 2851.91 due to Aliphatic C-H str.; 1704.91due to $\mathrm{C}=\mathrm{O}$ str.; 71.34, 1072.6 due to $\mathrm{C}-\mathrm{O}$ str., 1651.08, 1503.42, 1417.91 due to Aromatic $\mathrm{C}=\mathrm{C} ; 775.83$ due to Aromatic $\mathrm{C}-\mathrm{H}$ out of plane. The UV spectrum of isolated compound has characteristic bands at $\lambda 268 \mathrm{~nm}$ which lead to conclusion that the compound belongs to the group of Phenolic. HNMR \& C NMR was recorded on Bruker DRX -300 (300 MHz FT-NMR) in DMSO + D2O, using TMS as internal standard. H-NMR \& C-NMR spectral interpreted data of isolated compound from leaves of Cordia macleodii are mentioned in Table- 2. Mass spectrum of isolated compound from leaves of Cordia macleodii is shown below.<smiles>COc1cc(C(=O)O)cc(O)c1O</smiles>

Compound isolated from ethanolic extract of leaves of Cordia macleodii as fraction is light yellowish colour of melting point $260-262^{\circ} \mathrm{C}$, yellowish colour under UV light. Soluble in methanol, ethanol and water and identified as that the compound is the derivative of Gallic acid as interpreted from the different spectra.

\section{Conclusion}

Phytochemical screening of Cordia macleodii Hook may be useful to supplement information in respect to its identification, authentication and standardization of herbal drugs. In other words the pharmacognostic features examined in the present study may serve as tool for identification of the plant for validation of the raw materials and for standardization of its formations at herbal industrial level in the coming days.

\section{References}

[1]. Bhargav Bhide, A. P. G. Pillai,V. J. Shukla, R. N. Acharya, Pharmacognostic evaluation of leaf of Cordia macleodii Hook.: An ethnomedicinally important plant, Ayu, 2011, Volume: 32, Issue: 2, Pages: 254-257.

[2]. Dr. Om Narayan Chaubey, Dr. Ravi Upadhyay, Niraj Kumar Tripathi, Amulya Ranjan, "Phytochemicals analysis, Phenolic \& flavonoids content of Cordia macleodii Hook leaves \& Bark." International Journal of Phytomedicine, 7(2015) 231-234.

[3]. Dr.Om Narayan Chaubey, Dr. Ravi Upadhyay, Niraj Kumar Tripathi, Amulya Ranjan, "Comparative Antimicrobial Study of Cordia macleodii Hook" IOSR Journal of Pharmacy \& Biological Science (IOSR-JPBS), 2319-7676. Volume 10, Issue 3 Ver .I. (May-June 2015), PP 01-03.

[4]. Khandelwal, K.R. (2005). Ed. Practical Pharmacognosy Technique and Experiments, 23rd Edn: 15, 29, 149, 56.

[5]. Mukherjee PK. Herbal drugs-toxicity and regulations. In: Quality Control Herbal Drugs. New Delhi: Business Horizons, 2002, 3987.

[6]. Zgoda JR, Porter JR. A convenient microdilution method for screening natural products against bacteria and fungi. Pharm Biol 2001; 39: 221- 225. 
Table 1. Interpreted data of different spectra of isolated compound FROM Bark of bark of Cordia macleodii Hook

\begin{tabular}{|c|c|}
\hline Method & Spectral interpretation \\
\hline $\mathrm{UV}_{\max }$ & $256 \mathrm{~nm}$ and $371 \mathrm{~nm}$ \\
\hline IR & $\begin{array}{l}3495.12(\mathrm{OH}, \text { stretch }), 1696.43(\mathrm{C}=\mathrm{O} \text {, stretch }), 1610.55,1537.28,1427.20(\mathrm{C}=\mathrm{C} \text { stretch }), 1309.07(\mathrm{OH}, \text { In-plane } \\
\text { bend), 1246-1199 (C-O stretch), 1023.81 (OH, Out-plane bend), 864.49 (Ar-H,Out of plane bend). }\end{array}$ \\
\hline HNMR $(\delta \mathrm{ppm})$ & $\begin{array}{l}2.342-2.356(\mathrm{~s}, 3 \mathrm{H}) \mathrm{H}-1,6.349-6.351(\mathrm{~s}, 1 \mathrm{H}) \mathrm{H}-3,6.399-6.401(\mathrm{~s}, 1 \mathrm{H}) \mathrm{H}-5,6.481-6.483(\mathrm{~s}, 1 \mathrm{H}) \mathrm{H}-7,3.059-3.063 \text { \& } \\
2.808-2.810(\mathrm{~d}, 2 \mathrm{H} ; \mathrm{d}, 2 \mathrm{H}) \mathrm{H}-8 \text { \& H-10, 4.606-4.611(m, 1H) H-9, 5.898-5.899(s, 1H) H-14, 6.012-6.014(s, 1H) H-16 }\end{array}$ \\
\hline CNMR $(\delta \mathrm{ppm})$ & $\begin{array}{l}25.10 \mathrm{C} 1,140.05 \mathrm{C} 2,112.12 \mathrm{C} 3,158.56 \mathrm{C} 4,110.79 \mathrm{C} 5,139.46 \mathrm{C} 6,122.63 \mathrm{C} 7,43.11 \mathrm{C} 8,71.82 \mathrm{C} 9,45.99 \mathrm{C} 10, \\
195.99 \mathrm{C} 11,102.94 \mathrm{C} 12,163.12 \mathrm{C} 13,95.19 \mathrm{C} 14,164.94 \mathrm{C} 15,94.65 \mathrm{C} 16,159.78 \mathrm{C} 17\end{array}$ \\
\hline MASS (m/z) & 299.03 (Base peak) \\
\hline Structure & Mol. Wt. 300.31 \\
\hline IUPAC Name & 2-(3-hydroxy-5-methylbenzyl)2,3-dihydro-5,7-dihydroxychromen-4-one \\
\hline
\end{tabular}

Table 2. Interpreted data of different spectra of isolated compound from leaves of Cordia macleodii Hook

\begin{tabular}{|c|c|}
\hline Method & Spectral interpretation \\
\hline $\mathrm{UV}_{\max }$ & $268 \mathrm{~nm}$ \\
\hline IR & $\begin{array}{l}\text { stretching band at } 3259.95 \mathrm{~cm}^{-1} \text { (s) due to } \mathrm{OH} \text { stretching; at } 3015.23 \text { (s) due to Aromatic } \mathrm{CH} \text { str.; } 2932.28 \text {, } \\
2851.91 \text { due to Aliphatic } \mathrm{C}-\mathrm{H} \text { str.; } 1704.91 \text { due to } \mathrm{C}=\mathrm{O} \text { str.; } 71.34,1072.6 \text { due to } \mathrm{C}-\mathrm{O} \text { str., } 1651.08 \text {, } \\
1503.42,1417.91 \text { due to Aromatic } \mathrm{C}=\mathrm{C} ; 775.83 \text { due to Aromatic C-H out of plane }\end{array}$ \\
\hline H-NMR $(\delta$ ppm) & $7.000-7.032(\mathrm{~s}, 1 \mathrm{H}) \mathrm{H}-3,6.992-7.001(\mathrm{~s}, 1 \mathrm{H}) \mathrm{H}-7,3.712-3.732(\mathrm{~s}, 3 \mathrm{H}) \mathrm{H}-8$ \\
\hline C-NMR $(\delta$ ppm) & $170.12 \mathrm{C} 1,125.36 \mathrm{C} 2,108.59 \mathrm{C} 3,152.73 \mathrm{C} 4,139.68 \mathrm{C} 5,148.21 \mathrm{C} 6,109.82 \mathrm{C} 7,56.25$ \\
\hline MASS $(\mathrm{m} / \mathrm{z})$ & 183.20 (molecular ion) \\
\hline Structure & $\mathrm{Mol.} \mathrm{Wt.}{ }_{\mathrm{OH}}^{\mathrm{O}}$ \\
\hline IUPAC Name & 3,4-dihydroxy-5-methoxybenzoic acid \\
\hline
\end{tabular}

